\title{
DANA TALANGAN UMRAH DALAM PERSPEKTIF HUKUM ISLAM
}

\author{
Romli Ronan \\ Praktisi Biro Perjalanan Haji dan Umrah Bengkulu \\ J. Hibrida IV Kel. Sidomulyo Kec. Gading Cempaka, Kota Bengkulu \\ Email: romlironan@ymail.com
}

\begin{abstract}
Umrah worship is a worship that has high urgency in the life of Muslim communities in Indonesia. In addition to having a high value of merit beside Allah SWT, umrah worship is also an opportunity for every Muslim to set foot for worship in two holy cities glorified by the Creator. The high number of devotees of worship is shown by the increasing number of umrah worshipers and umrah service bureaus from year to year. Along with this, more and more practice of bailouts in umrah worship, both through banking and non-banking bailouts. The phenomenon that is a problem is how the real concept of istitha'ah in umrah worship in Islamic teachings, and also how it reviews Islamic law on umrah worship by using bailouts. The researcher used three theories as scalpel to discuss the issue under study. The three theories in question include maslahah al-mursalah, qiyas, and fiqh rules (qawa'id al-fiqhiyyah). By using a conceptual approach and supported by secondary data, the results obtained that istitha'ah in umrah worship have similarities with istitha'ah in the pilgrimage, namely the ability of both physical and material to go to the holy land. The utilization of bailouts in umrah worship depends on the condition of the pilgrims who are reluctant, as well as the nature and form of bailouts provided. The five legal provisions apply by looking at the economic situation and the ability of someone who does an Umrah trip.
\end{abstract}

Keywords: Loan Funds, Umrah, Islamic law

\begin{abstract}
Abstrak: Ibadah umrah merupakan ibadah yang memiliki urgensi tinggi di dalam kehidupan masyarakat muslim di Indonesia. Selain memiliki nilai pahala yang tinggi di sisi Allah Swt., ibadah umrah juga merupakan kesempatan bagi setiap muslim untuk menginjakkan kakinya guna beribadah di dua kota suci yang diagungkan oleh Sang Pencipta. Tingginya angka peminat ibadah ini ditunjukkan dengan makin banyaknya peserta ibadah umrah dan biro jasa umrah dari tahun ke tahun. Seiring dengan hal tersebut, makin banyak pula praktik dana talangan di dalam ibadah umrah, baik melalui dana talangan perbankan maupun non-perbankan. Fenomena yang menjadi persoalan ialah bagaimana sesungguhnya konsep istitha' ah pada ibadah umrah dalam ajaran Islam, dan bagaimana pula tinjauan hukum Islam terhadap ibadah umrah dengan menggunakan dana talangan. Peneliti menggunakan tiga buah teori sebagai pisau bedah dalam membahas isu yang diteliti. Ketiga teori yang dimaksud meliputi maslahah al-mursalah, qiyas, dan kaidah-kaidah fikih (qawa’id al-fiqhiyyah). Dengan menggunakan pendekatan konsep dan didukung dengan data-data sekunder, diperoleh hasil bahwa istitha'ah dalam ibadah umrah memiliki kesamaan dengan istitha'ah dalam ibadah haji, yakni kemampuan baik fisik dan materi untuk berangkat ke tanah suci. Adapun pemanfaatan dana talangan dalam ibadah umrah tergantung dengan kondisi jamaah yang berumrah, serta sifat dan bentuk talangan dana yang diberikan. Ketentuan hukum yang lima berlaku dengan melihat keadaan ekonomi dan kemampuan dari seseorang yang melakukan perjananan umrah.
\end{abstract}

Kata kunci: Dana Talangan, Umrah, hukum Islam

\section{Pendahuluan}

Ibadah umrah merupakan kewajiban setiap muslim sebagaimana ibadah haji. Allah swt. perintahkan di dalam Alquran Surat AlBaqarah/2: 196:

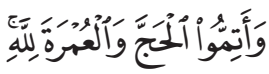

"Dan sempurnakanlah ibadah haji dan 'umrah karena Allah...”.
Rasulullah saw. menegaskan urgensi umrah di dalam hadis sejajar dengan keutamaan jihad, yaitu:

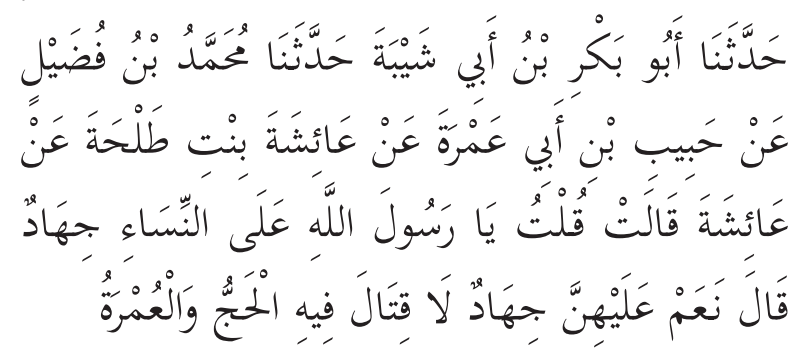


"Telah menceritakan kepada kami, Abu Bakar bin Abu Syaibah, telah menceritakan kepada kami Muhammad bin Fudhail dari Habib bin Abu Amrah, dari 'Aisyah binti Thalhah dari 'Aisyah, ia bertanya: "Aku bertanya: 'Ya Rasulullah, adakah kewajiban jihad atas wanita?' Beliau menjawab: 'Ya, atas mereka ada kewajiban jihad yang tidak peperangan didalamnya, yaitu:Haji dan umrah." (HR.Ibnu Majah No. 2892) ${ }^{1}$

Ibadah umrah merupakan ibadah yang memiliki prestise tersendiri di dalam masyarakat Indonesia di samping ibadah haji. ${ }^{2}$ Hal tersebut dibuktikan dengan makin banyaknya jamaah yang melaksanakan ibadah umrah setiap tahunnya. Masyarakat yang lebih memilih melaksanakan ibadah umrah memiliki alasan bahwadi dalam ibadah umrah terdapat adanya rentang waktu yang panjang, tidak seperti ibadah haji di mana terdapat daftar tunggu peserta sebagaimana ketentuan yang dikoordinir oleh pemerintah Indonesia. Disamping ada perasaan pesimis dapat melaksanakan ibadah haji melalui daftar tunggu-utamanya bagi masyarakat yang berusia lanjut, ibadah umrah dianggap sebagai kategori ibadah yang fleksibel dalam pelaksanaannya sehingga ibadah tersebut dapat dilaksanakan dalam waktu-waktu yang dikompromikan dengan pekerjaan.

Umrah dapat dideskripsikan sebagai sebagai ibadah pengantar sebelum melaksanakan ibadah haji di tahun-tahun berikutnya. Hal itu merupakan suatu bentuk motivasi lain terkait alasan seseorang berangkatumrah. Umrah yang dilaksanakan sebagai pendahuluan tersebut dianggap sebagai pembelajaran agar dapat melaksanakan ibadah haji dengan lebih nyaman pada kesempatan berikutnya. Selain itu ada pula yang melakukan ibadah umrah sebagai kedatangan kedua, ketiga, atau kesekian kalinya

\footnotetext{
${ }^{1}$ Kitab Hadis Digital Mausu'ah al-Hadis al-Syarif, lihat juga hadis senada di dalam Musnad Imam Ahmad, Hadis No. 24158.

2 Umrah merupakan ibadah yang wajib menurut mazhab Syafi'i dan mazhab Hambali, sedangkan menurut mazhab Hanafi dan mazhab Maliki, ibadah umrah tersebut hukumnya sunnah mu'akkad. Wahbah Zuhaili menukil pendapat Imam Syafi'i bahwa hadis yang digunakan sebagai dalil oleh mazhab Hanafi dan mazhab Maliki merupakan hadis dhaif. Lihat Wahbah al-Zuhaili, al-Fiqh alIslam wa Adillatuhu, (Damaskus: Dar al-Fikr, 1996), h. 18-19.
}

setelah selesai melaksanakan ibadah haji.

Fenomena menjamurnya biro layanan ibadah haji di berbagai penjuru tanah air menunjukkan bahwa semakin banyak jamaah umrah yang berasal dari tanah air. Kondisi ini kemudian dimanfaatkan oleh kalangan usaha perbankan untuk mengembangkan usaha di segmen pasar pemberangkatan ibadah umrah. Pihak-pihak perbankan kemudian berlomba-lomba menciptakan model-model pembiayaan yang berkualitas dalam bidang jasa dana talangan pemberangkatan haji maupun umrah. Jasa dana talangan dibuat sedemikian rupa dari program yang terlihat jelas kesan eksplorasi terhadap umat hingga program yang secara halus menjerat masyarakat ke dalam "hutang baik" yang diganjar pahala dan penghapusan dosa. Kondisi tersebut berakibat pada makin banyaknya masyarakat yang tertarik mengikuti ibadah umrah dengan jasa dana talangan dari pihak perbankan. Keadaan yang demikian menyebabkan syarat istitha'ah dalam umrah terkesan terabaikan, orang-orang lebih banyak melihat keuntungan dan kemudahan ibadah umrah dengan menggunakan jasa pendanaan yang dipinjamkan oleh pihak perbankan dibandingkan syarat-syarat umrah itu sendiri. Pada satu sisi, talangan umrah tersebut mengandung unsur positif, tapi di sisi lain juga mengandung unsur negatif, karena banyak masyarakat yang memaksakan diri untuk umrah. Padahal, dalam ajaran Islam, beban melaksanakan suatu ibadah hanya ditujukan kepada mukallaf (Islam, baligh, berakal dan mampu). Hal tersebut tentu kurang sesuai dengan salah satu prinsip ajaran Islam yaitu: الحرجعدم (tidak menyulitkan).

Allah Swt. berfirman dalam Alquran Surat alBaqarah/2: 185, yaitu:

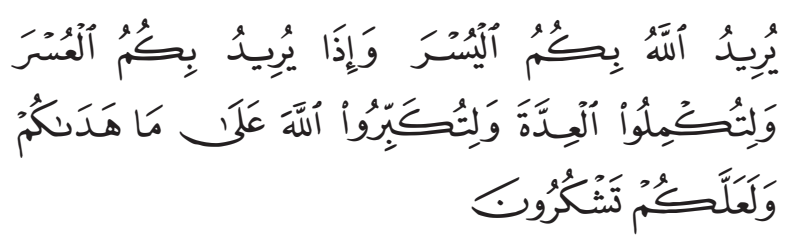

"Allah menghendaki kemudahan bagimu, dan tidak menghendaki kesukaran bagimu. dan hendaklah kamu mencukupkan bilangannya dan hendaklah kamu mengagungkan Allah atas petunjuk-Nya yang diberikan kepadamu, supaya kamu bersyukur". 
Berdasarkan ayat di atas, dapat dipahami bahwa Allah Swt menghendaki kemudahankemudahan, termasuk dalam hal umrah. Sehingga ibadah umrah yang dilakukan dengan menggunakan jasa dana talangan, perlu didalami lebih lanjut status hukumnya.

Allah Swt juga berfirman dalam Alquran surat Al-Hajj/27: 78 menyatakan hal yang sama dengan surat Al-Baqarah/2: 185, yaitu:

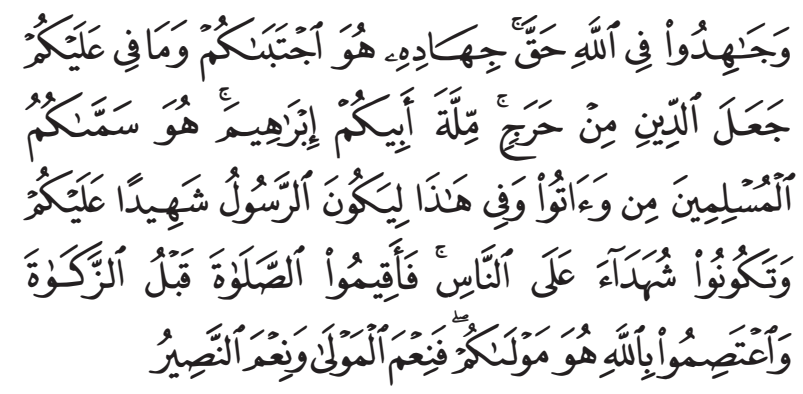

"Dan berjihadlah kamu pada jalan Allah dengan Jihad yang sebenar-benarnya. Dia telah memilih kamu dan Dia sekali-kali tidak menjadikan untuk kamu dalam agama suatu kesempitan. (Ikutilah) agama orang tuamu Ibrahim. Dia (Allah) telah menamai kamu sekalian orang-orang Muslim dari dahulu, dan (begitu pula) dalam (Alquran) ini, supaya Rasul itu menjadi saksi atas dirimu dan supaya kamu semua menjadi saksi atas segenap manusia, Maka dirikanlah sembahyang, tunaikanlah zakat dan berpeganglah kamu pada tali Allah. Dia adalah Pelindungmu, Maka Dialah Sebaik-baik pelindung dan sebaik-baik penolong”. (QS. Al-Hajj/22: 78)

Peneliti melihat adanya urgensi untuk meneliti persoalan jasa dana talangan umrah lebih dalam, sehingga didapatkan keterangan-keterangan yang dapat dipegang sebagai dasar pelaksanaan ibadah umrah dengan memanfaatkan fasilitas jasa pinjaman baik dari lembaga maupun dari perorangan.Berdasarkan latar belakang diatas, maka tulisan ini akan memberikan jawaban tentang bagaimana konsep istitha'ah pada ibadah umrah dalam ajaran Islam dan bagaimana tinjauan hukum Islam terhadap ibadah umrah dengan menggunakan dana talangan.

\section{Umrah dan Haji}

Abdul Aziz Muhammad Azzam dan Abdul Wahhab Sayyed Hawwas ${ }^{3}$ menyatakan bahwasanya haji menurut arti bahasa (etimologi) berarti al-qashd ila mu'azhzham (pergi menuju sesuatu yang diagungkan. Sedangkan menurut arti istilahnya (terminologi) dimaknai hanya untuk niatan datang ke Baitullah guna menunaikan ritual-ritual peribadatan (manasik) tertentu. ${ }^{4}$ Sehingga ibadah haji dapat diartikan sebagai suatu keberangkatan menuju Baitul Haram untuk menunaikan aktifitas tertentu pada waktu tertentu, atau dapat juga dimaknai dengan pergi mengunjungi tempat-tempat tertentu ${ }^{5}$ dengan perilaku tertentu ${ }^{6}$ pada waktu tertentu ${ }^{7}$.

Menurut syara', haji berarti amal-amal tertentu yang dilakukan pada waktu tertentu di tempat tertentu dengan cara tertentu. Haji adalah ibadah fardhu yang harus dilakukan seketika. Oleh karenanya, orang yang telah memenuhi syarat wajib haji harus segera menunaikannya (QS. Ali Imran/3: 97). ${ }^{8}$

Abdul Aziz Muhammad Azzam dan Abdul Wahhab Sayyed Hawwas menyatakan bahwa umrah menurut arti bahasa berarti mengunjungi. Kalimat "itaarahu" bersinonim dengan "zaarahu", yang berarti mengunjunginya. Umrah juga disebut sebagai haji kecil karena ia memiliki persamaan dengan haji dalam hal ihram, thawaf, sai, dan tahallul (mencukur/memangkas rambut). Sedangkan menurut arti syara', umrah adalah ziarah ke Baitul Haram dengan mekanisme tertentu, yakni dengan ihram, thawaf, sai, dan tahallul. Di sini tidak dikatakan "pada waktu tertentu", karena umrah boleh dilakukan kapanpun.

\footnotetext{
${ }^{3}$ Abdul Aziz Muhammad Azzam dan Abdul Wahhab Sayyed Hawas adalah Guru Besar di Fakultas Syari'ah wa al-Qanun, Universitas al-Azhar Mesir.

${ }^{4}$ Abdul Aziz Muhammad Azzam dan Abdul Wahhab Sayyed Hawwas, Figh Ibadah: Thaharah, Shalat, Zakat, Puasa, dan Haji, (Jakarta: Amzah, 2010), h. 481-482.

${ }^{5}$ Ka'bah di Makkah, Shafa dan Marwa, Muzdalifah, dan Arafah.

${ }^{6}$ Ihram, sa'i, dan wukuf.

${ }^{7}$ Bulan Syawal, Dzulqaidah, dan 10 (sepuluh) hari bulan Dzulhijjah.

${ }^{8}$ Asmaji Muchtar, Dialog Lintas Mazhab: Fiqh Ibadah dan Muamalah, (Jakarta: Amzah, 2015), h. 269.
} 
Ibadah umrah ialah ibadah yang memiliki tiga rangkaian ritual yaitu: tawaf, sä, dan tahallul. Dengan melaksanakan rangkaian ibadah tersebut maka selesailah ibadah umrah." Kata "umrah" diambil dari kata "al-itimar" yang berarti ziarah (berkunjung). Sedangkan yang dimaksud dengan umrah adalah berkunjung ke Ka'bah dengan melaksanakan thawaf mengelilinginya, sä ${ }^{\prime}$ antara Shafa dan Marwah, dan mencukur atau memotong rambut. Para ulama sepakat bahwa umrah adalah ibadah yang disyariatkan. ${ }^{10}$

Menurut Kamus Besar Bahasa Indonesia, umrah adalah kunjungan (ziarah) ke tempat suci (sebagai bagian dari upacara naik haji, dilakukan setiba di Makkah) dengan cara berihram, tawaf, säi, dan bercukur, tanpa wukuf di Padang Arafah, yang pelaksanaannya dapat bersamaan dengan waktu haji atau di luar waktu haji. Ia juga disebut haji kecil. ${ }^{11}$

Imam Syafi'i menjelaskan ada tujuh perkara yang menjadi syarat wajib haji dan ada lima rukun dalam ibadah haji, sebagaimana yang dikutip oleh Musthafa Dib al-Bigha yaitu:

$$
\begin{aligned}
& \text { وشرائط وجوب الحج سبعة أشياء: الإسلام، والبلوغ, } \\
& \text { والعقل، والحرية، ووجودالزاد والراحلة، وتخلية الطريق، } \\
& \text { وإمكان المسير ولعمل وحريه }
\end{aligned}
$$

"Syarat wajib haji ada tujuh perkara, yaitu: Beragama Islam, baligh, berakal, merdeka, memiliki perbekalan dan adanya kendaraan, jalan yang aman, serta mampu untuk melakukan perjalanan". ${ }^{12}$

$$
\begin{aligned}
& \text { وأركان الحخ خمسة: الإحرام مع النية، والوقوف بعرفة، } \\
& \text { والطواف، والسعي بين الصفا والمروة، والحلق }
\end{aligned}
$$

"Rukun haji ada lima, yaitu: Ihram disertai niat, Wukuf di Arafah, Thawaf di Baitullah, Säi

${ }^{9}$ H. M. Iwan Gayo, Buku Pintar Haji dan Umrah, Jakarta: Pustaka Warga Negara, 2012, h. 344.

${ }^{10}$ Sulaiman Ahmad Yahya al-Faif, Ringkasan Fikih Sunnah Sayyid Sabiq, (Jakarta: Pustaka Al-Kautsar, 2013), h. 389.

${ }^{11}$ Kbbi.web.id/umrah (diakses tanggal 2 Desember 2015, Pukul 10.15 WIB)

${ }_{12}$ Musthafa Dib al-Bugha, Fikih Islam Lengkap: Penjelasan Hukum-hukum Islam Madzhab Syafi'i, (Solo: Media Zikir, 2009, h. 228. di antara Shafa dan Marwa, Halq (mencukur rambut)". ${ }^{13}$

Berkenaan dengan syarat wajib di atas, Imam Syafi'i sebagaimana yang dikutip oleh Abdurrahman al-Juzairi menguraikan:

1. Ibadah haji diwajibkan bagi seorang muslim mukhallaf..$^{14}$ Sedangkan orang yang murtad. Jika orang yang murtad meninggal dunia setelah dia kembali memeluk agama Islam namun dia belum berhaji maka diwajibkan kepada ahli waris untuk melaksanakannya;

2. Ibadah haji tidak diwajibkan bagi anak kecil yang belum mencapai usia baligh. Apabila seorang anak kecil yang sudah mencapai usia mumayiz melaksanakan ibadah haji dan dia sudah memahami manasiknya, maka hajinya dianggap sah, namun dia tetap harus melakukannya lagi setelah dia sudah mencapai usia baligh;

3. Ibadah haji tidak diwajibkan untuk dilaksanakan oleh orang yang tidak waras akalnya, jika dia melakukannya maka hajinya tidak sah. Adapun orang yang tidak waras itu layaknya seorang anak kecil yang belum mumayiz;

4. Ibadah haji tidak diwajibkan bagi hamba sahaya yang belum merdeka;

5. Ibadah haji tidak diwajibkan bagi orang yang tidak mampu. Seluruh ulama sepakat bahwa orang yang tidak mampu tidak diwajibkan melaksanakannya (QS. Ali Imran/3: 97). Namun, para ulama berbeda pendapat mengenai maksud dari kemampuan untuk kaum wanita dan orang-orang yang berkebutuhan khusus. ${ }^{15}$

Adapun mengenai rukun pelaksanaan ibadah haji menurut mazhab Syafi'i, Abdurrahman al-

${ }^{13}$ Musthafa Dib al-Bugha, Fikih Islam Lengkap: Penjelasan Hukum-hukum Islam Madzhab Syafi'i..., h. 230.

${ }^{14}$ Beragama Islam adalah syarat wajib haji menurut mazhab Hanafi, Syafi'i, dan Hanbali. Sedangkan menurut mazhab Maliki, beragama Islam adalah syarat sah, bukan syarat wajib. Sehingga orang kafir wajib melakukan haji meskipun tidak sah, kecuali dengan masuk Islam. Lihat Asmaji Muchtar, Dialog Lintas Mazhab: Fiqh Ibadah dan Muamalah..., h. 269.

15 Abdurrahman al-Jaziri, Fikih Empat Mazhab, Jilid 2, (Jakarta: Pustaka Al-Kautsar, 2015), h. 499-501. 
Juzairi menyatakan bahwa ia terdiri dari Ihram, Tawaf,Sai, Wukuf di Arafah memiliki beberapa persyaratan dan kesunahan. Syarat wukuf di Arafah adalah hadir di tanah Arafah tepat waktu, waktu wukuf adalah sejak matahari tergelincir pada hari tanggal 9 (sembilan) Dzulhijjah hingga terbit fajar pada hari raya Idul Adha; ${ }^{16}$ Sedikit berbeda dengan ibadah haji, ibadah umrah memiliki rukun tersendiri yang terdiri dari empat hal yaitu:

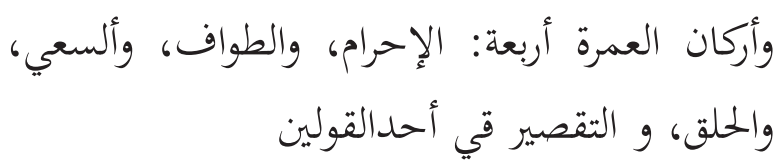

"Rukun umrah ada empat, yaitu: Ihram, Thawaf, Säi, dan Mencukur gundul atau memendekkannya menurut satu dari dua pendapat."17

Haji dan umrah memiliki arti penting di dalam kehidupan umat Islam. Apabila pada salat jamaah, salat jumat, dan salat dua hari raya mengandung hikmah berhimpunnya kaum muslimin dengan baris-berbaris sebagai tanda persatuan umat; maka haji dan umrah merupakan kelanjutan dari rancangan Allah swt. untuk menyatukan kaum muslimin dalam jumlah yang lebih besar. Pada pelaksanaan haji dan umrah, umat muslim yang berasal dari beragam ras, berbagai latar belakang, dan dari berbagai penjuru dunia berkumpul di satu tempat dan dalam satu waktu.Mutawalli alSyárawi di dalam kitabnya yang berjudul Anta Tas'alu wa al-Islaamu Yujiibu, menyatakan bahwa:

"Ibadah haji adalah himpunan dan ikatan yang kokoh serta merupakan muktamar internasional yang unik, yang diserukan oleh Allah yang satu, ditetapkan tempat dan waktu yang satu, digariskan ajaran-Nya dengan kitab yang satu, lewat Rasul yang satu, disambut oleh kaum muslimin dengan pakaian yang satu dan dengan maksud dan tujuan yang satu pula. Dalam kesatuan itulah dilebur jenis, warna kulit, bahasa, fanatisme golongan, suku bangsa, dan kedudukan. Tidak ada kebanggaan silsilah

${ }^{16}$ Abdurrahman al-Jaziri, Fikih Empat Mazhab, Jilid 2..., h. 511-550. Penambahan satu rukun lagi dalam pendapat yang lainnya yaitu: Tertib antara semua rukun, lihat Abdurrahman al-Jaziri, Fikih Empat Mazhab, Jilid 2..., h. 602; dan Zainuddin 'Abdul 'Aziz al-Malibariy, Fathul Mu'in, (Kudus: Menara Kudus, 1980), h. 112.

${ }^{17}$ Musthafa Dib al-Bugha, Fikih Islam Lengkap: Penjelasan Hukum-hukum Islam Madzhab Syafi'i..., h. 233. keturunan, kecuali dengan Islam dan tidak ada pangkat, kedudukan dan jabatan, kecuali dalam keimanan. Itulah kekhususan yang harus diambil sebagai ikatan antarbangsa dengan landasan cinta dan kasih sayang.Ibadah haji merupakan sarana untuk mempelajari situasi dan kondisi kawan-kawan muslimin di negaranegara lain, baik mereka yang mayoritas maupun yang minoritas. Dengan demikian, terhimpun kekompaka dan kekuatan menghadapi segala tantangan dan kemungkinan sehingga umat Islam menjadi umat sebagaimana disifatkan oleh Nabi saw., sebagai susunan batu bata yang rapi dan saling menguatkan bagi bangunan yang kokoh.Apabila Islam dihadapkan pada ancaman oleh musuh-musuhnya, harapan mereka adalah mempersatukan barisan dengan rencana, arah tujuan, dan perjuangan yang serentak.Dengan demikian, dapat diambil manfaat dari peranan umat Islam di muka bumi, sedangkan pertemuan tahunan memiliki bobot, kemampuan, dan kewibawaan yang diperhitungkan oleh dunia". ${ }^{18}$

'Ali Jum'ah juga memberikan penjelasan yang rajih ketika ditanyakan mengenai hikmah pertemuan umat Islam pada ibadah haji/umrah. Ia menyatakan bahwa:

"Umat Islam adalah umat tauhid. Ibadah haji mengingatkan kita bahwa yang terkandung dalam tauhid begitu tinggi dan mulia, leih dari sekedar pengesaan Allah saja seperti yang mungkin diyakini sebagian orang. Umat Islam mengesakan Tuhannya, percaya kepada satu nabi, yaitu nabi dan rasul terakhir: Muhammad saw., dalam melakukan salat menghadap satu kiblat, berpedoman pada satu Kitab Suci yang tidak mengandung kebatilan sedikitpun, karena Allah telah menjamin akan memeliharanya dan menjadikannya sebagai mukjizat kenabian Muhammad saw.Di antara makna tauhid adalah bahwa umat ini harus bersatu, karena Tuhan mereka satu, rasul mereka satu, Kitab Suci mereka satu, akidah mereka satu, salat mereka satu, haji mereka juga satu. Ibadah haji/umrah mengingatkan kita kepada kewajiban untuk menciptakan kesatuan umat.Umat Islam saat ini tersebar sangat luas.Dari Tangier di Maroko sampai Jakarta di Indonesia." ${ }^{19}$

${ }^{18}$ Mutawalli al-Sya'rawi, Anta Tas'alu wa al-Islaamu Yujiibu (Anda Bertanya Islam Menjawab), (Jakarta: Gema Insani Press, 2007), h. 441-442.

19 'Ali Jum'ah, Syaikh Ali Jum'ah Menjawab 99 Soal 
Ali Ahmad al-Jurjawi ${ }^{20}$ juga menyatakan bahwa haji dan umrah akan memupuk rasa persaudaraan. Mereka akan saling kenal mengenal dan berkasih sayang. Orang Arab akan mengenal orang India, orang Turki akan mengenal orang Cina, orang Mesir mengenal orang Syria. Orang Maroko mengenal orang Indonesia, begitulah seterusnya. Mereka menjadi seperti saudara seibu sebapak karena ikatan agama, tanpa ada perbedaan kabilah atau warna kulit. ${ }^{21}$ Persatuan dan persaudaraan seperti itu selain mendatangkan manfaat besar bagi kaum muslimin, juga mengandung manfaat lain yaitu mengenal kondisi perdagangan, pertanian, dan bentuk usaha masing-masing dan terjadi saling tukar pengalaman, budaya, barang, dan lain-lain (QS.Al-Hajj/22: 28).

Lebih jauh lagi, Ali Ahmad al-Jurjawi menyatakan bahwa haji dan umrah memiliki urgensifitas tersendiri yang masing-masingnya dapat dijelaskan sebagai berikut:

1. Ibadah haji dan umrah membersihkan akhlak: Umat Islam yang memunaikan ibadah haji umumnya mengalami perubahan yang bertahap. Dimulai dari taubat yang dilakukan sebelum keberangkatan ke tanah suci. Bilamana ada seorang jamaah haji melakukan perbuatan dosa misalnya, maka orang-orang di sekitarnya mengingatkannya atau mencelanya karena menurut mereka tindakan tercela tidaklah layak dilakukan oleh seorang yang menyandang predikat haji;

2. Urgensi Ihram: Ihram menunjukkan sikap rendah hati di hadapan Allah swt. demikian pula saat bersimpuh di depan kebesaran Allah swt dikala melaksanakan wukufdi Arafah. Hal yang demikian bermakna ketundukan dan kepatuhan serta kesamaan derajat di hadapan Allah swt;

3. Urgensi Wukuf: Wukuf ialah mengikuti jejak nabi adalah dasar dalam penentuan waktu wukuf di Arafah yang dengannya kaum

Keislaman, (Tangerang: Lentera Hati, 2014), h. 113.

20 Direktur Asosiasi Riset Ilmiah Universitas Al-Azhar, Kairo, Mesir.

${ }^{21}$ Ali Ahmad al-Jurjawi, Indahnya Syariat Islam, (Jakarta: Pustaka Al-Kautsar, 2013), h. 175. muslimin memohon ampunan dosa dari Allah swt. Wukuf di Arafah dapat diartikan pula sebagai bentuk pengorbanan demi memperoleh ampunan Allah swt., sebab seorang muslim yang melakukannya harus meninggalkan sanak saudara dan kampung halamannya demi memenuhi panggilan Allah swt;

4. Urgensi Säi antara Shafa dan Marwah: Shafa dan Marwah adalah dua tempat untuk pelaksanaan $s a \mathfrak{i}$, dengan melakukan sa $i$ dari Shafa ke Marwah, seorang jamaah haji meminta kepada Allah swt. kebutuhan dan rahmat-Nya yang sangat luas, sebagaimana telah diberikan kepada Sayyidah Hajar dan putranya Nabi Ismail. ${ }^{22}$

Berdasarkan beberapa urgensi di atas, maka dapat disimpulkan bahwa ibadah haji memiliki hikmah yang besar di dalam kehidupan umat Islam. Selain mengandung pesan persamaan derajat di hadapan Allah swt., rangkaian ibadah haji juga menjadi sarana bersatunya seluruh umat Islam di dunia sehingga dari sanalah berbagai manfaat dunia dan akhirat dapat diambil.

Para Imam Mazhab telah sepakat bahwa haji merupakan salah satu rukun Islam. Ia adalah fardhu yang diwajibkan atas setiap muslim yang merdeka, baligh, dan mempunyai kemampuan, dalam seumur hidup sekali. Namun demikian, para Imam Mazhab berbeda pendapat mengenai hukum umrah. Umrah hukumnya sunnah muakkad menurut Imam Hanafi dan Imam Maliki, sedangkan Imam Hambali menyatakan bahwa umrah hukumnya adalah fardhu sebagaimana haji. ${ }^{23}$ Menurut mazhab Syafi'i, ibadah haji adalah ibadah fardhu yang dapat ditunda. Penundaan keberangkatan tidak dianggap maksiat apabila memenuhi dua hal: Pertama, tidak khawatir terlewatkan karena usia atau karena hartanya tersia-sia. Jika ada kekhawatiran dengan hal tersebut, maka haji wajib dilakukan pada tahun itu juga; Kedua, mempunyai niat yang kuat

\footnotetext{
${ }^{22}$ Ali Ahmad al-Jurjawi, Indahnya Syariat Islam..., h. 191-193.

${ }_{23}$ Muhammad bin Abdurrahman al-Dimasyqi, Fiqih Empat Mazhab, (Bandung: Hasyimi, 2013), h. 161. Lihat juga Sulaiman Ahmad Yahya al-Faifi, Ringkasan Fiqh Sunnah Sayyid Sabiq..., h. 390.
} 
akan berangkat haji pada tahun mendatang. ${ }^{24}$ Para ulama sepakat, bahwa waktu umrah adalah sepanjang tahun, boleh melaksanakannya pada hari kapan pun. Abu Hanifah ra., berpendapat bahwa umrah hukumnya makruh pada lima hari yaitu: Hari Arafah, Idul Adha, dan tiga hari Tasyriq. Sedangkan waktu yang paling utama adalah pada bulan Ramadhan. ${ }^{25}$ Ulama Malikiyah dan ulama Hanafiyah berpendapat bahwa umrah hukumnya sunnah muakkad, yaitu umrah sekali seumur hidup. Pendapat yang paling kuat dari Imam Syafi'i dan menjadi pendapat ulama Hambali bahwasanya umrah hukumnya wajib sekali seumur hidup. ${ }^{26}$ Imam Syafi'i menggariskan ketentuan fardhuatas ibadah umrah dengan landasan Alquran Surat Al-Baqarah/2: 196, selanjutnya—sebagaimana yang dikutip oleh Asmaji Muchtar, Imam Syafi'i menyatakan bahwa hukum haji sama dengan hukum umrah. Seseorang boleh umrah atas nama orang lain seperti kebolehan haji atas nama orang lain. Demikian juga tidak sah umrah atas nama orang lain, kecuali pelaku umrah merdeka, baligh, dan muslim. ${ }^{27}$

\section{Dana Talangan dan Penggunaannya dalam Ibadah Umrah}

Kamus Besar Bahasa Indonesia menjelaskan bahwa kata "dana" adalah uang yang disediakan untuk suatu keperluan, juga disebut biaya, pemberian, hadiah, derma. ${ }^{28}$ Kata "dana talangan" adalah istilah yang umumnya digunakan di dalam dunia ekonomi. Dunia perbankan mendefinisikan dana talangan sebagai "dana yang disediakan oleh Bank Indonesia yang digunakan untuk melakukan pembayaran terlebih dahulu kepada kreditur bank yang akan menjadi hutang bank tersebut kepada Bank Indonesia”. ${ }^{29}$ Menurut Ahmad

\footnotetext{
${ }^{24}$ Asmaji Muchtar, Dialog Lintas Mazhab: Fiqh Ibadah dan Muamalah..., h. 269.

${ }^{25}$ Muhammad bin Abdurrahman al-Dimasyqi, Fiqih Empat Mazhab..., h. 161

${ }^{26}$ Muhammad Qasim Kamil, Halal Haram dalam Islam, (Depok: Mutiara Allamah Utama, 2014), h. 212.

${ }^{27}$ Asmaji Muchtar, Fatwa-fatwa Imam Asy-Syafi'i: Masalah Ibadah, (Jakarta: Amzah, 2014), h. 296.

28 www.kbbi.web.id/dana (diakses tanggal 2 Desember 2015, Pukul 10.17 WIB)

29 www.mediabpr.com/kamus-binsis-bank/dana_talangan. aspx (diakses tanggal 2 Desember 2015, Pukul 10.22 WIB)
}

Ifham Solihin ${ }^{30}$, dana talangan ialah dana yang disediakan oleh Bank Indonesia yang digunakan untuk melakukan pembayaran terlebih dahulu kepada kreditur bank dan akan menjadi utang bank tersebut kepada Bank Indonesia. ${ }^{31}$ Dalam tataran yang lebih luas, maka dana talangan dapat dimaknai sebagai sejumlah uang yang disediakan oleh pihak ketiga yang digunakan untuk melakukan pembayaran terhadap kebutuhan peminjamnya. Berdasarkan keterangan-keterangantersebut, maka dapat disimpulkan bahwasa dana talangan umrah ialah suatu perjanjian/akad dimana pihak kedua meminjamkan sejumlah uang kepada pihak pertama (peminjam) guna keperluan pelaksanaan ibadah umrah baik separuhnya ataupun seluruhnya.

Terdapat beberapa bentuk dana talangan yang dapat digunakan untuk membiayai keberangkatan haji maupun umrah. Bentukbentuk dana talangan yang dimaksud dapat dijelaskan sebagai berikut:

1. Pinjaman dari Pihak Perbankan: Pinjaman dari pihak perbankan dikenal dalam istilah "dana untuk pinjaman" (loanable fund). Dalam dunia ekonomi, loanable fund didefinisikan sebagai dana yang tersedia dalam bank yang dapat dipergunakan untuk keperluan pemberian pinjaman kepada pihak ketiga. ${ }^{32}$ Berdasarkan definisi di atas, maka dana talangan dari pihak perbankan ialah dana yang dikucurkan oleh lembaga perbankan kepada nasabahnya untuk membiayai suatu keperluan, biasanya bantuan tersebut diberikan dengan agunan berupa benda-benda tidak bergerak semisal tanah, rumah, kebun, sawah ataupun yang lainnya.

2. Pinjaman dari Pihak Ketiga Non-perbankan: Pinjaman dari pihak non-perbankan ialah dana yang dikucurkan oleh lembaga nonperbankan kepada seseorang untuk membiayai

${ }^{30}$ Ahmad Ifham Solihin ialah seorang Project Officer KARIM Business Consulting, Business Analyst for Sharia Banking PT. Multipolar \&Sharia Business Consultant PT. Anabatic Teknologi. Implementator Aplikasi Sharia Core Banking System T24 (TEMENOS) di 2 (dua) Bank Syariah terbesar di Indonesia.

${ }^{31}$ Ahmad Ifham Solihin, Buku Pintar Ekonomi Syariah, (Jakarta: PT. Gramedia Pustaka Utama, 2010), h. 225.

${ }^{32}$ Ahmad Ifham Solihin, Buku Pintar Ekonomi Syariah... 
suatu keperluan. Bantuan yang diberikan tersebut dapat berupa pinjaman tanpa agunan, ataupun dapat juga berupa pinjaman yang disertai jaminan-jaminan pengembalian yang sifatnya sederhana. Pinjaman perorangan (baik pinjaman tanpa agunan maupun dengan agunan) dan pinjaman melalui lembaga Koperasi dapat menjadi contoh dalam hal dana talangan non-perbankan. Biasanya pinjaman jenis ini diperoleh dari keluarga, sanak famili atau kerabat, tetangga, dan pihak non-bank lainnya yang dinilai mampu secara finansial untuk mendanai perjalanan umrah. Pinjaman melalui koperasi dapat juga dijadikan jalan untuk memperoleh sejumlah dana guna keberangkatan ke Tanah Suci dengan catatan si peminjam telah menjadi anggota dari koperasi tersebut.

3. Dana Talangan melalui Arisan: Arisan ialah kegiatan mengumpulkan uang atau barang yang bernilai sama oleh beberapa orang, kemudian diundi di antara mereka untuk menentukan siapa yang memperolehnya, undian dilaksanakan dalam sebuah pertemuan secara berkala sampai semua anggota memperolehnya. ${ }^{33}$ Seseorang dapat saja berangkat umrah dengan memanfaatkan hasil arisan yang ia ikuti, baik arisan yang berwujud uang tunai maupun arisan yang memang khusus diadakan untuk biaya umrah. Baik dalam arisan uang tunai maupun arisan umrah, setiap peserta yang mendapatkan undian dapat berangkat ke Tanah Suci dengan didanai oleh anggota arisan yang lain. Kondisi ini berlangsung terusmenerus hingga seluruh anggota memperoleh kesempatan yang sama untuk melaksanakan umrah secara bergiliran.

Akad dalam istilah berarti ikatan dan tali pengikat. Makna akad secara bahasa ialah menghubungkan antara dua perkataan, masuk juga di dalamnya janji dan sumpah, karena sumpah menguatkan niat berjanji untuk melaksanakan isi sumpah atau meninggalkannya. Demikian juga halnya dengan janji sebagai

${ }^{33}$ www.kbbi.web.id/arisan (diakses pada hari Senin, 24 Juli 2017, Pukul 14.54 WIB). perekat hubungan antara kedua belah pihak yang berjanji dan menguatkannya. ${ }^{34}$ Menurut Abdul Aziz Muhammad Azzam ${ }^{35}$, secara terminologi, akad bermakna ikatan, pengokohan dan penegasan dari satu pihak atau kedua belah pihak. Makna secara bahasa ini sangat sesuai dengan apa yang dikatakan oleh kalangan ulama fiqh, di mana didapati kalangan ulama fiqh yang menyebutkan bahwa akad adalah setiap ucapan yang keluar sebagai penjelas dari dua keinginan yang ada kecocokan, sebagaimana mereka juga menyebutkan arti akad sebagai setiap ucapan yang keluar yang mnenerangkan keinginan walaupun sendirian. ${ }^{36}$ Adapun makna akad secara syar'i yaitu hubungan antara ijab dan qabul dengan cara yang dibolehkan oleh syariat yang mempunyai pengaruh secara langsung. Hal tersebut bermakna bahwa akad termasuk dalam kategori hubungan yang mempunyai nilai menurut pandangan syara' antara dua orang sebagai hasil dari kesepakatan antara keduanya yang kemudian dua keinginan itu dinamakan ijab dan qabul. ${ }^{37}$ Terdapat beberapa syarat dan rukun akad, yaitu: Ijab dan qabul, Mukhallaf, Obyek akad, Tujuan akad sesuai syara. ${ }^{38}$

Berkenaan dengan dana talangan umrah, akad-akad yang mungkin untuk dilakukan diantaranya ialah:

1. Akad hutang-piutang/pinjam-meminjam. Adapun bentuknya dapat berupa pinjaman barang ataupun uang, sedangkan menurut sifatnya, Islam menekankan jenis pinjaman yang bersifat sosial (nir-laba) tanpa mencari keuntungan.

2. Akad Pinjam (Pinjaman Non-Kredit): Penerima pinjaman (muqtaridh) tidak boleh mengembalikan kepada pemberi pinjaman

${ }^{34}$ Abdul Aziz Muhammad Azzam, Figh Muamalat: Sistem Transaksi dalam Fiqh Islam, (Jakarta: Amzah, 2010), h. 15.

35 Abdul Aziz Muhammad Azzam adalah seorang Guru Besar di Fakultas Syari'ah wa al-Qanun, Universitas Al-Azhar Kairo, Mesir.

${ }^{36}$ Abdul Aziz Muhammad Azzam, Fiqh Muamalat: Sistem Transaksi dalam Figh Islam..., h. 15-16.

${ }^{37}$ Abdul Aziz Muhammad Azzam, Figh Muamalat: Sistem Transaksi dalam Fiqh Islam..., h. 17.

${ }^{38}$ Asep Saepudin Jahar, Hukum Keluarga, Pidana \& Bisnis, (Jakarta: Kencana Prenadamedia Group, 2013), h. 261. 
(muqridh) keuali apa yang telah dipinjamnya atau yang sepadan dengannya tanpa adanya tambahan dan kelebihan. Hal tersebut mengikuti kaidah fiqh yang mengatakan "Setiap pinjaman yang mendatangkan keuntungan adalah riba". Tetapi, pengharaman ini hanya berlaku ketika tambahan tersebut disyaratkan dan disepakati oleh kedua pelaku transaksi qardh pada saat transaksi dilakukan. Jika tidak disyaratan dan disepakati, si penerima pinjaman diperbolehkan untuk menambah kuantitas (takaran dan timbangan) atau kualitas barang yang dipinjamnya. Si pemberi pinjaman memiliki hak untuk menagih atau meminta kembali apa yang dipinjakannya, tetapi dengan tanpa unsur paksaan. ${ }^{39}$

3. Akad Pinjaman Kredit: Kredit adalah sesuatu yang pembayarannya ditunda sampai waktu yang ditentukan di mana pembayarannya dicicil dalam jumlah cicilan tertentu, dan setiap cicilan mempunyai batas masa pembayaran tertentu. ${ }^{40}$ Berkaitan dengan dana talangan umrah, bahwa seseorang memperoleh sejumlah uang melalui pihak kedua kemudian dipergunakan untuk membiayai keperluan-keperluan ibadah umrah. Adapun pelunasannya digunakanlah akad kredit, yaitu mencicil biaya umrah baik melalui lembaga perbankan dan atau yang lainnya.

4. Akad Gadai (Rahn): Menggadaikan barang berharga guna memperoleh sejumlah uang untuk membiayai keberangkatan ke Tanah Suci adalah jalan lain selain meminjam uang di lembaga perbankan ataupun meminjam uang kepada pihak non-perbankan. Perbuatan yang demikian dikenal dengan sebutan rahn.

Berkenaan dengan istitha'ah, terdapat beragam pendapat mazhab yang memaknainya. Istitha'ah dalam umrah memiliki kaitan dengan mabrurnya ibadah umrah.Mabrur adalah ibadah yang sempurna hukum-hukumnya sehingga

${ }^{39}$ Sulaiman Ahmad Yahya al-Faif, Ringkasan Fikih Sunnah Sayyid Sabiq..., h. 791.

${ }^{40}$ Abdul Aziz Mabruk al-Ahmadi, dkk., Figh Muyassar: Panduan Praktis Fikih dan Hukum Islam, (Jakarta: Darul Haq, t.th.), h. 357. terlaksana secara sempurna sebagaimana yang dituntut. $^{41}$

\section{Ibadah Umrah dengan Dana Talangan}

Istitha'ah merupakan bagian substantif yang harus dikemukakan sebelum membahas persoalan dana talangan umrah. Untuk itu pada sub bab pertama ini perlu dikemukakan terlebih dahulu mengenai persoalan istitha'ah (kesanggupan) dalam ibadah umrah dan hal-hal yang berkenaan dengannya.

Sayyid Sabiq menyatakan bahwa istitha'ah dalam ibadah haji dan umrah yaitu:

"Istitha'ah terealisasi dengan terpenuhinya beberapa persyaratan wajib, yaitu: Pertama, seorang mukhallaf harus sehat badan, apabila ia merasa lemah untuk melaksanakan ibadah haji karena ketuaan atau sakit yang tidak ada harapan sembuhnya maka ia wajib dihajikan oleh orang lain apabila ia berharta; Kedua, perjalanan dalam keadaan aman di mana seseorang yang berhaji merasa aman atas diri dan hartanya. Apabila ia khawatir terjadi perampokan atas atas dirinya, atau adanya wabah penyakit, atau khawatir akan kehilangan hartanya, maka dia termasuk orang yang tidak mampu melakukan perjalanan ibadah haji/umrah; Ketiga dan keempat, harus memiliki perbekalan dan harus memiliki kendaraan. Adapun yang termasuk perbekalan bahwa ia harus memiliki apa yang mencukupi untuk memenuhi kebutuhan dirinya dan mencukupi orang yang menjadi tanggungannya yakni perbekalan yang lebih dari cukup dari kebutuhan aslinya berupa kebutuhan pakaian, tempat, dan kendaraan. Sehingga ia dapat melaksanakan kewajiban dan kembali. Adapun yang termasuk kendaraan ialah yang memungkinkan baginya untuk pergi dan pulang, baik melalui jalan darat maupun jalan laut, ataupun melalui udara; Kelima, tidak ada hal yang menghalangi manusia dari keberangkatan menuju haji/umrah seperti adanya penahanan atau takut terhadap penguasa yang lalim." ${ }^{42}$

Komite Tetap Kajian Hukum Ilmiah dan Fatwa Arab Saudi memfatwakan bahwa istitha'ah atau kemampuan dalam haji dan umrah me-

${ }^{41}$ Muhammad Quraish Shihab, Haji dan Umrah Bersama M. Quraish Shihab: Uraian Manasik, Hukum, Hikmah, \& Panduan Meraih Haji Mabrur, (Tangerang: Lentera Hati, 2012).h. 519.

42 Sayyid Sabiq, Fiqhu al-Sunnah, (Beirut: Daar al-Fikr, 1983), h. 531-533. 
miliki syarat substantif yang meliputi: Badan yang sehat, ada kendaaraan yang mengantar sampai ke Masjidil Haram, biaya dan bekal yang cukup sesuai dengan keadaan. Perbekalan tersebut harus merupakan kelebihan dari nafkah orang-orang yang menjadi tanggungannya sampai dia kembali dari ibadahnya. ${ }^{43}$

Selain itu terdapat pula pendapat Abu Bakar Jabir al-Jazairi, Syamsuddin Abu 'Abdillah Muhammad bin Qosim asy-Syafi'i, dan Imam Taqiyuddin Abubakar bin Muhammad al-Husaini. Pada intinya mereka bersepakat bahwa istitha'ah itu meliputi beberapa hal yang wajib dipenuhi oleh seseorang untuk menjalani ibadah umrah:

1. Niat yang kuat disertai dengan perbekalan keuangan yang mencukupi, baik untuk dipergunakandalam melaksanakan ibadah umrah maupun bagi keluarga yang ditinggalkan;

2. Fisik atau kesehatan yang prima, baik sehat secara fisik maupun sehat secara mental;

3. Kendaraan yang memadai dan memungkinkan untuk tiba di Tanah Suci;

4. Keamanan dalam perjalanan dari hal-hal yang mengganggu, semisal adanya penjahat, musuh, peperangan, atau hal lainnya yang dapat merintangi ibadah.

Keempat hal di atas seluruhnya harus terpenuhi oleh seseorang yang berkeinginan berangkat ke Tanah Suci.Dalam hal satu syarat tidak terpenuhi maka konsekuensinya ialah seseorang tersebut tidak wajib berumrah.

Allah Swt. mewajibkan ibadah haji hanya kepada orang yang mampu, terlebih lagi ibadah umrah. Allah Swt. berfirman di dalam Alquran Surah Ali Imran/3: 97:

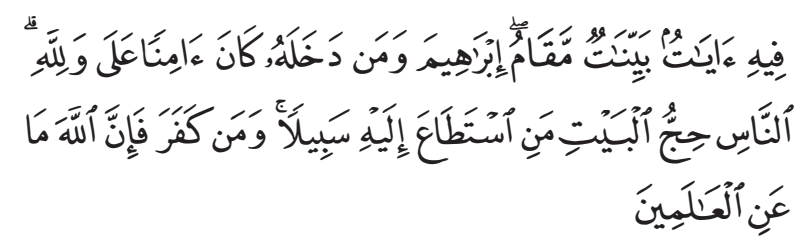

"Padanya terdapat tanda-tanda yang nyata, (di antaranya) maqam Ibrahim, barangsiapa me-

\footnotetext{
${ }^{43}$ Muhammad bin 'Abdul 'Aziz al-Musnad, Fatwa-fatwa Haji dan Umrah, (Jakarta: Pustaka Imam Asy-Syafi'i, 2007), h. 60.
}

masukinya (Baitullah itu) menjadi amanlah dia, mengerjakan haji adalah kewajiban manusia terhadap Allah, yaitu (bagi) orang yang sanggup mengadakan perjalanan ke Baitullah. Siapa yang mengingkari (kewajiban haji), maka Sesungguhnya Allah Maha Kaya (tidak memerlukan sesuatu) dari semesta alam".

Dengan demikian, secara umum didapatkan keterangan berkenaan dengan calon jamaah umrah yang berhutang, yaitu bahwa ia harus mendahulukan kewajiban membayar hutangnya. Apabila setelah itu ia memperoleh kemudahan dalam berhaji/berumrah, maka ia dapat melaksanakan ibadah tersebut. Sekalipun jika hutangnya lebih sedikit dari hartanya, maka secara umum hutangnya haruslah didahulukan pembayarannya sebelum melaksanakan ibadah itu setelah hutangnya dilunasi. Kondisi keumuman tersebut berlaku baik haji wajib maupun haji sunah. Akan tetapi, persoalan akan menjadi berbeda ketika seseorang yang pada mulanya tidak memiliki hutang, kemudian sengaja berhutang demi berangkat ke Tanah Suci.

Berdasarkan penelitian yang dilakukan, terdapat dua pandangan yang berseberangan berkenaan dengan ibadah haji ataupun umrah dengan menggunakan dana talangan. Pertama, pendapat yang membolehkan umrah dengan berhutang menggunakan dana talangan; dan kedua, pendapat yang tidak membolehkannya. Kedua pendapat tersebut dapat diuraikan dalam dua butir bahasan di bawah ini:

\section{Argumentasi Haramnya Hutang dalam Ibadah Umrah}

Sejatinya, baik ibadah haji maupun ibadah umrah haruslah terlepas dari beban hutang dalam bentuk apapun. Imam Syafi'i berpendapat bahwa, "Barangsiapa yang tidak mendapatkan kemudahan dan kelebihan harta yang menjadikannya dapat menunaikan ibadah haji tanpa melakukan pinjaman, maka ketika itu dia dianggap tidak layak untuk pergi haji. ${ }^{44}$

\footnotetext{
${ }^{44}$ Imam Syafi'i, Al-Umm 2/116, Kitab Digital Maktabah Syamilah.
} 
Pendapat di atas disepakati oleh Lajnah Daimah (Komite Tetap Kajian Hukum Ilmiah dan Fatwa) Arab Saudi yang disarikan oleh tiga orang ulama asal Saudi yaitu 'Abdul Aziz bin 'Abdullah bin Baz, Muhammad bin Shalih al'Utsaimin, dan 'Abdullah bin 'Abdurrahman alJibrin.

Muhammad bin Shalih al-Utsaimin sebagaimana dikutip oleh Muhammad bin 'Abdul 'Aziz al-Musnad,menyatakan bahwa jika seseorang mempunyai hutang senilai semua hartanya, maka dia tidak wajib berhaji, sebab Allah swt. mewajibkan haji hanya kepada orang mampu. Kewajiban yang harus didahulukan adalah membayar hutang. Jika setelah itu mendapat kemudahan untuk berhaji, maka dia boleh berhaji/berumrah. Tetapi jika hutangnya lebih sedikit dari nilai hartanya sehingga dia mampu berhaji/umrah setelah membayar hutang, maka dia membayar hutangnya lebih dahulu lalu dia pergi haji, baik haji wajib maupun sunah. Namun, untuk haji yang wajib harus segera dilakukan, sedang haji sunah terdapat pilihan. Jika mau, dia boleh pergi haji, dan jika tidak pergi haji maka tiada dosa baginya. ${ }^{45}$ Muhammad bin Shalih al-'Utsaimin memberikan pengecualian bagi orang yang berangkat haji dalam kondisi masih meninggalkan hutang yang tidak ditentukan pembayarannya dan pemberi hutang tidak berada di negera Arab Saudi. Ia menyatakan bahwa seseorang boleh berhaji sebelum membayar hutang dan hajinya sah. Namun, hutang tetap harus dibayar dan tidak boleh berhaji bila pemberi hutang mendesak untuk pembayarannya. Pada kondisi pemberi hutang memberikan kemudahan dalam hal pembayarannya sekembali dari Arab Saudi maka hal tersebut tidak menghalangi seseorang yang memiliki hutang untuk melakukan ibadah haji. ${ }^{46}$

'Abdul 'Aziz bin 'Abdullah bin Baz menambahkan bahwa seseorang yang tidak

\footnotetext{
${ }^{45}$ Muhammad bin 'Abdul 'Aziz al-Musnad, Fatwa-fatwa..., h. 67-68.

${ }^{46}$ Muhammad bin 'Abdul 'Aziz al-Musnad, Fatwa-fatwa..., h. 68-69.
}

mempunyai biaya haji karena harus membayar hutang, maka tidaklah wajib berhaji sesuai dengan QS. Ali Imran/3: $97 .{ }^{47}$

Selanjutnya 'Abdul 'Aziz bin 'Abdullah bin Baz, sebagaimana yang dikutip oleh Muhammad bin 'Abdul 'Aziz al-Musnad, menjelaskan bahwa jika seseorang berkeinginan menunaikan haji dengan uang pinjaman—baik pinjaman dari tempat bekerja yang nantinya akan dikembalikan secara tunai ataupun cicilan, maka cara yang dilakukan tersebut sebenarnya dapat dibenarkan. Akan tetapi, yang utama dan lebih baik adalah tidak melakukan itu. Sebab Allah swt. hanya mewajibkan haji kepada orang yang mampu, sedangkan peminjam uang adalah orang yang saat ini belum berada dalam kapasistas kemampuan. Ia menekankan bahwa sebaiknya orang yang akan berangkat ke Tanah Suci tidak meminjam uang untuk berhaji/berumrah. Sebab si peminjam tidak mengetahui, barangkali hutang itu masih dalam tanggungan sedangkan si peminjam tidak mampu membayarnya setelah itu, misalnya karena sakit atau tempat kerja mengalaami kebangkrutan atau meninggal dunia. Maka, semestinya tidak berhutang untuk berhaji sampai seseorang tersebut mampu berangkat dengan dananya sendiri. ${ }^{48}$

Nabi saw. ketika ditanya oleh Abdullah bin Abi Aufa ra.:

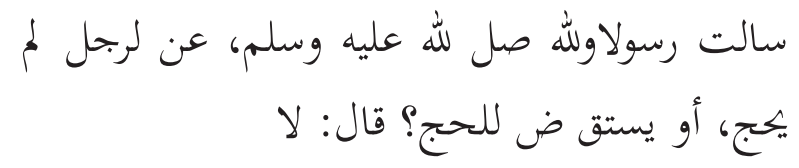

"Aku bertanya kepada Nabi saw berkenaan seorang lelaki yang belum menunaikan haji, apakah ia boleh meminjam uang untuk haji?"Nabi saw menjawab: "Tidak". ${ }^{49}$

Sesungguhnya agama Islam tidak memberatkan kepada siapapun untuk bisa berangkat ke Tanah Suci guna melakukan ibadah haji maupun umrah, dengan catatanseseorang tersebut benar-benar telah memiliki kemampuan

\footnotetext{
${ }^{47}$ Muhammad bin 'Abdul 'Aziz al-Musnad, Fatwa-fatwa..., h. $70-71$.

${ }^{48}$ Muhammad bin 'Abdul 'Aziz al-Musnad, Fatwa-fatwa..., h. 71-72.

${ }^{49}$ Imam Syafi'i, Al-Musnad Asy-Syafi'i: 1/109; Al-Umm: 2/116, Kitab Digital Maktabah Syamilah.
} 
dan bukan sesuatu yang dipaksakan sebelum tiba saatnya. Berkenaan dengan persoalan ini, IbnualQudamah al-Maqdisijuga menyatakan bahwa:

"Dan hendaklah (perbekalan ini) adalah harta berlebih dari yang dia perlukan untuk menafkahi keluarganya yang wajib disediakannya semasa kepergiannya sampai kepulangannya. Hal itu dikarenakan nafkah keluarga berkaitan dengan hak manusia dimana mereka lebih membutuhkan dan hak mereka lebih diutamakan...Selain itu, hendaklah perbekalannya dari harta berlebih sehingga dia mampu melunasi hutangnya. ${ }^{50}$

Yusuf al-Qardhawi menambahkan bahwa seseorang yang masih tersangkut dengan beban hutang tidak wajib untuk menunaikan haji. Para ulama sependapat bahwa 'bekal' yang dimaksudkan oleh Nabi saw adalah kelebihan harta berbanding tanggungan pokoknya, jusru hutangnya terhadap individu perseorangan adalah termasuk dalam tanggungjawab pokoknya seperti juga nafkah wajib. Selain itu, hutang individu perseorangan yang bersifat jangka pendek harus diselesaikan sebelum pergi menunaikan haji. ${ }^{51}$

Muhammad Arifin Badri mencatat setidaknya ada tiga alasan mengapa haji/umrah dengan menggunakan dana talangan tidak boleh dilakukan, yaitu: akadnya dilarang oleh Nabi Muhammad saw., mengandung riba terselubung, dan sangat berpotensi menyusahkan masyarakat. ${ }^{52}$ Berikut penjelasan tiga alasan keharaman umrah dengan dana talangan sebagaimana yang dimaksud oleh Muhammad Arifin Badri: Akadnya dilarang oleh Nabi Muhammad saw, adanya Riba Terselubung, memberatkan Masyarakat.

Melakukan ibadah haji dengan keyakinan akan membawa mudharat kepada kewajiban terhadap pemilik hutang baik dari kalangan individu ataupun perbankan, maka hukumnya adalah haram.Berdasarkan argumentasi-

50 Ibnu al-Qudamah, Al-Mughni: 4/317, Kitab Digital Maktabah Syamilah.

${ }^{51}$ Tim Konsultasi Syariah Rumah Zakat, "Hukum Naik Haji tetapi Berhutang", https://www.rumahzakat.org/hukumnaik-haji-tetapi-berhutang-3/, diakses pada hari Kamis, 3 Agustus 2017, Pukul 13.06 WIB.

52 Muhammad Arifin Badri, "Berhaji dari Talangan Bank", https://almanhaj.or.id/3167-berhaji-dari-talangan-bank.html, diakses pada hari Kamis, 3 Agustus 20117, Pukul 13.16 WIB. argumentasi di atas, maka hukum umrah dengan menggunakan fasilitas dana talangan dari pihak ketiga sebaiknya tidak dilakukan untuk menjaga kemurnian dan kemabruran umrah.

\section{Argumentasi Kebolehan Berhutang dalam Umrah}

Tidak ada perdebatan mengenai keberangkatan umrah dengan dana talangan yang bukan berupa hutang. Terlebih lagi yang membiayai keberangkatannya ke Tanah Suci adalah keluarganya sendiri, misalnya orang tua, saudara kandung, anak, ataupun cucu.

Masyfuk Zuhdi berpendapat bahwa orang tua yang berkeinginan keras melakukan ibadah haji/umrah namun kondisi keuangannya kurang memungkinkan, tetapi anak-anaknya mampu, baik secara individual maupun secara kolektif menanggung biaya hajinya, maka menurut syara', anak-anaknya wajib memenuhi keinginan orang tuanya apabila secara medis tidak ada halangan untuk melakukan perjalanan haji. ${ }^{53}$ Pun demikian untuk keberangkatan saudari perempuan yang biayanya ditalangi oleh saudaranya laki-laki, sebagaimana yang dikemukakan oleh 'Ali Jum'ah. ${ }^{54}$ Sebab keduanya merupakan pemberian (hibah) yang merupakan suatu kewajaran dan bukan berupa transaksi hutang-piutang. Yang menjadi persoalan adalah bagaimana jika biaya keberangkatan ke Tanah Suci itu merupakan dana pinjaman perorangan atau lembaga keuangan perbankan.

Imam Syafi'i dalam fatwanya, sebagaimana yang dikutip oleh Asmaji Muchtar, membuka kemungkinan mengenai hutang-piutang dalam persoalan pembiayaan keberangkatan ibadah haji/umrah. Ia menyatakan bahwa:

"Jika seseorang tidak mempunyai harta yang mencukupi untuk haji, ia tidak boleh hutang untuk biaya haji. Ia tidak termasuk mampu dalam melakukan perjalanan haji. Akan tetapi, jika ia mempunyai materi yang banyak; ia harus menjual

\footnotetext{
53 Masjfuk Zuhdi, Masail Fiqhiyah, Jakarta: PT. Toko Gunung Agung, 1997, h. 286.

54 'Ali Jum'ah, Syaikh Ali Jum'ah Menjawab 99 Soal Keisalaman, Tangerang: Lentera Hati, 2014, h. 112.
} 
sebagian materinya, hutang dengan jaminan materi tersebut, atau menyewa demi menunaikan ibadah haji. Ia juga mempunyai tempat tinggal (rumah), bahan makanan, dan pembantu yang ia tinggalkan untuk keluarganya selama haji. Jika ia mempunyai biaya untuk haji, namun tidak mampu memberi nafkah keluarga yang ia tinggal di rumah, maka nafkah keluarga selama ia pergi lebih wajib. Jika ada orang yang mau menanggung nafkah keluarganya, baik dengan sukarela maupun dengan upah, hal itu tidak menodai keabsahan hajinya. Orang tersebut boleh menerima upah, baik kaya maupun miskin." 55

Berdasarkan fatwa di atas, maka hutang-piutang dalam persoalan pembiayaan keberangkatan ibadah haji/umrah itu dimungkinkan. Imam Syafi’ $\mathrm{i}$ memberikan tiga solusi untuk memberangkatkan seseorang ke Tanah Suci yaitu: (1) menjual harta miiknya untuk membiayai keberangkatan, (2) hutang dengan jaminan materi/harta, (3) menyewa demi menunaikan ibadah haji.

Fatwa serupa dikeluarkan oleh ulama lainnya, salah satunya Muhammad bin Shalih al-Utsaimin. Kendatipun banyak mengeluarkan fatwa yang keras dalam tataran ibadah, alUtsaimintercatat pernah mengeluarkan fatwa yang fleksibel berkenaan dengan dana talangan haji/umrah. Ia menyatakan bahwa:

"Ibadah haji/umrah dengan uang dari utangan tidak merusak sahnya ibadah. Apalagi bila di balik utang itu ada tujuan yang mulia, yaitu menemani orangtua, atau wanita yang tidak memiliki mahram. Seseorang tidak wajib menunaikan ibadah haji/umrah jika ia sedang menanggung utang, tapi tidak menggugurkan syarat sahnya. Sebagian ulama, berpandangan; jangan berutang untuk menunaikan ibadah haji/umrah, karena ibadah haji/umrah dalam kondisi seperti itu hukumnya tidak wajib. Dengan kemurahan rahmat Allah swt, seseorang hendaknya tidak memaksakan diri dengan berutang, yang ia sendiri tidak tahu kapan dapat melunasinya, bahkan barangkali ia mati dan belum sempat menunaikan utangnya. Lalu jika begitu ia menanggung beban hutang selama-lamanya". ${ }^{56}$

55 Asmaji Muchtar, Fatwa-fatwa Imam Syafi' : Masalah Ibadah, Jakarta: Amzah, 2011, h. 286-287.

${ }_{56}$ Muhammad bin Shalih al-Utsaimin, Fatawa Nur alad Darb,Jilid 1, Kitab Digital Maktabah Syamilah.
Berdasarkan fatwa al-Utsamin di atas, maka dibolehkan berumrah dengan uang yang diperoleh dari berhutang, dan akan lebih dibolehkan lagi jika memang keberangkatan ke Tanah Suci tersebut memiliki tujuan-tujuan lain yang mulia seperti mendampingi mahram, menemani orang tua, atau hal-hal lainnya yang mengakibatkan kesulitan apabila tidak dilakukan.

Menurut peneliti, terdapat tiga kaidah fikih yang dapat dipakai dalam menghadapi persoalan di atas, yakni kaidah fiqh:al-masyaqqatu tajlibu at-taysir, ri'ayah al-dharurati wa al-hajah, dan attakhfif wa at-taysir la at-tasydid wa at-ta'sir.

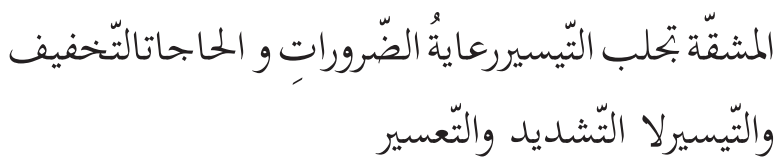

Berdasarkan ketiga kaidah fikih di atas, maka seseorang yang berangkat ke Tanah Suci dengan memanfaatkan dana talangan adalah dibolehkan asalkan memperhatikan keterpaksaan dan kebutuhan. Memperhatikan keterpaksaan dan kebutuhan maksudnya ialah ada unsur keterpaksaan dan/atau ada unsur kebutuhan yang bila tidak dipenuhi akan menyulitkan. Keadaan yang menyulitkan seseorang dapat membuka kemudahan-kemudahannya dalam menjalankan perintah agama, termasuk juga dalam perkara umrah. Dengan terpenuhinya kemudahankemudahan maka secara otomatis akan meringankan dan mempermudah bukan memberatkan dan menyulitkan suatu proses menuju ibadah umrah. Adapun meringankan dan memudahkan suatu perkara adalah lebih utama ketimbang memberatkan dan menyulitkan.

Majelis Ulama Indonesia(MUI) sebagai representasi pemerintah dalam persoalan umat Islam memperbolehkan mekanisme penggunaan dana talangan dalam pelaksanaan haji dengan suatu persyaratan. Mekanisme pinjaman ke bank untuk pelaksanaan haji dibolehkan, asalkan tidak ada imbalan atau komisi dalam talangannya. Komisi hanya boleh diterapkan perbankan dalam proses pengurusannya saja, tidak untuk cicilan bulanannya. ${ }^{57}$

57 M. Risyal Hidayat, TEMPO, "MUI: Boleh Berhaji 
Ibadah umrah dengan menggunakan dana talangan hukumnya adalah sah menurut Nahdhatul Ulama (NU). Kebolehan ibadah umrah dengan dana talangan dapat dilihatdalam Keputusan Muktamar Nahdhatul Ulama (NU) ke-28 di Pondok Pesantren al-Munawir, Krapyak, Yogyakarta pada tanggal 26-29 Rabi'ul Akhir 1410 H/25-28 Nopember 1989 M.Keputusan Muktamar Nahdhatul Ulama (NU) memuat konsiderans kitab al-Syarqawi dan Nihayah al-Muhtaj sebagai sandaran pendapat. Kedua argumentasi hukum berikut ini dapat menjelaskan mengenai keabsahan haji dan umrah dengan menggunakan dana talangan perbankan, termasuk juga pembiayaan melalui arisan. Organisasi Islam terbesar di Indonesia ini menggunakan kitab al-Qulyubi, kitab Nihayatu al-Muhtaj, kitabasy-Syarqawi sebagai landasan terbitnya fatwa. ${ }^{58}$

"Perkumpulan yang populer (misalnya arisan) di kalangan wanita, di mana masing-masing dari wanita tersebut mengeluarkan sejumlah tertentu (uang) dan memberikannya kepada salah seorang dari mereka secara bergantian sampai giliran yang terakhir, maka yang demikian itu sah. Demikianlah penjelasan al-Wali Iraqi.Pinjaman secara syar'i adalah, memberikan hak milik sesuatu dengan mengembalikan penggantinya. Menurut Ali asy-Syibramalisyi sebagaimana pendapat dalam al-Minhaj, adalah dengan mengembalikan persis sama dengan barang yang dipinjamnya, dan gambaran (perkiraan) dalam barang yang dinilai.

Ungkapan redaksi dengan kata pengganti di atas, adalah agar sesuai dengan pendapat yang kuat, bahwa pinjaman itu harus mengembalikan persis sama betul dengan barang yang dipinjamnya dalam hal barang yang memang ada padanannya, atau sama dalam bentuknya dalam hal barang yang diperhitungkan nilainya.

dengan Uang Pinjaman Bank", https://m.tempo.co/read/ news/2012/10/11/136435001/mui-bolehkan-berhaji-denganuang-pinjaman-bank, diakses pada hari Kamis, 3 Agustus 2017, Pukul 14.42 WIB.

${ }^{58}$ Kitab al-Qulyubi, Juz II, hal. 258; Kitab Nihayatu alMuhtaj, Juz II, hal. 219 dan Juz III, hal. 233; serta Kitab asySyarqawi, Juz I, hal. 460.
Sah haji orang fakir dan semua orang yang tidak mampu selama ia termasuk orang yang merdeka dan mukallaf (muslim, berakal, baligh) sebagaimana sah orang yang sakit yang memaksakan diri untuk memaksakan salat Jum'at" (Nihaayah al-Muhtaj, 3/233 dan alSyarqawi 1/460)). ${ }^{59}$

Selain Nahdhatul Ulama (NU), organisasi Islam lainnya juga membolehkan berangkat umrah dengan menggunakan fasilitas dana talangan. Majelis Tarjih dan Tajdid PP Muhammadiyah berpendapat bahwa "tidak ada halangan bagi orang yang melakukan ibadah haji dengan harta pinjaman dari orang lain. Asalkan halal. Haji yang dilakukan dengan harta demikian kalau sesuai dengan agama, sah hukumnya, dan hajinya pun dapat saja mencapai haji mabrur", dengan catatan dana talangan hasil pinjaman tersebut bukan mengada-ada secara tidak semestinya (takaluf) atau pinjaman tanpa sumber pengembalian/"asal pinjam".Bagi orang yang mempunyai harta (benda) dan kemampuan untuk mengembalikan pinjaman utang, meminjam uang untuk berhaji tidak menjadi masalah. Misalnya, seseorang yang sudah berniat haji, tetapi pada saat pelunasan Ongkos Naik Haji (ONH), barang yang akan dijual untuk biaya haji belum laku. Kemudian ia pinjam atau berutang kepada saudara atau temannya. Sesudah pulang dari haji barang itu baru laku dan dikembalikan pinjaman tersebut. ${ }^{60}$

Menggunakan dana talangan dalam menunaikan ibadahumrah boleh jadi justru menunjukkan bahawa seseorang itu memiliki kemampuan berumrah. Perbuatan tersebut seolah-olah menunjukkan ketidakmampuan seseorang, akan tetapi dari paradigma berbeda dapat ditemukan kenyataan bahwa seseorang yang berhutang untuk ibadah umrah pada jalur prosedural sesungguhnya memiliki kemampuan dalam membayar hutangnya. Dengan istilah

59 M. Jamaluddin Miri (pent.), Abkamul Fuqaha: Solusi Problematika Aktual Hukum Islam, Keputusan Muktamar, Munas, dan Konbes Nahdhatul Ulama (1926-2004 M), (Jawa Timur: Lajnah Ta’lif Wan Nasyr [LTN], 2007) , h. 412.

${ }^{60}$ Tim Penulis, "Hukum Berhaji dengan Pinjaman Bank dan Arisan Haji”, http://www.jadipintar.com/2013/08/HukumBerhaji-Dengan-Pinjaman-Bank-dan-Arisan-Haji.html, diakses pada hari ... Pukul 14.31 WIB. 
lainnya, seseorang yang berhutang untuk berangkat ke Tanah Suci dianggap belum memiliki kelayakan dan belum cukup bekal, namun secara hakiki terdapat kemampuan membayar yang terkandung dalam kemampuan berhutang yang ia lakukan. Hanya saja, kemampuan tersebut memerlukan sedikit waktu dalam pelunasanya.

Menurut hemat peneliti, apabila hutang pinjaman itu tidak mengganggu keseluruhan tanggung jawabnya dalam menafkahi keluarganya, boleh jadi karena ia memilikiaset atau harta lainnya yang bisa dijual saat diperlukan, maka melakukan pinjaman untuk berangkat ke Tanah Suci boleh saja dilakukan. Keadaan tersebut sesuai dengan apa yang diucapkan oleh Imam Syafi'i di dalam kitabnya bahwa: “... jika ia mempunyai harta yang banyak, ia boleh menjual sebagiannya atau berhutang (karena yakin dapat membayar hutang yang dipinjamnya)." ${ }^{\prime 1}$

Harus dibedakan jenis hutang individu (individual debt) dengan hutang kepada perbankan (corporate debt) yang memakan jangka waktu yang lama. Pembiayaan terstruktur kepada perbankan atau lembaga keuangan lainnya masuk dalam kategori pinjaan yang dapat ditolerir, utamanya bagi mereka yang mengangsur pembayaran melalui pemotongan gaji. Hutang dari jenis perbankan tidaklah menghalangi kelayakan seseorang untuk menunaikan haji asalkankeberangkatannya ke Tanah Suci tidak akan menimbulkan masalah terhadap pembayaran hutang sistematik sebagai konsekuensi dari pinjaman yang dilakukaan. Kondisi berbeda jikaseseorang meyakini bahwa kepergiannya ke Tanah Suci dapat menyebabkan merusakneraca keuangan yang berimplikasi kepada rusaknya tanggungjawab wajibnya (nafkah keluarga) sekaligusmemberatkan akibat hutang yang wajib dibayarkan kepada pihak ketiga yang meminjamkan dana. Apabila itu terjadi maka umrah dengan menggunakan dana talangan tidak boleh dilakukan, sebab segala sesuatu yang diyakini membawa kepada

\footnotetext{
${ }^{61}$ Imam Syafi'i, al-'Umm: 2/116, Kitab Digital Maktabah Syamilah.
}

yang haram, maka hukumnya juga haram. Sebagaimana kaidah figh: "Apa-apa yang membawa kepada yang haram, hukumnya adalah haram" "Abdul Karim bin Abdullah al-Khudhair juga berpendapat bahwa"jika ia berharap mampu untuk melunasi hutang tersebut, dan menurut dugaan kuat ia memang mampu untuk melunasinya, maka insya Allah tidak mengapa ia berhutang untuk membiayai ibadah haji. Adapun apabila menurut dugaan kuat ia tidak mampu melunasi hutang tersebut, maka hukum asalnya ia tidak wajib melaksanakan haji." ${ }^{63}$

Berdasarkan dua pendapat di atas, baik pendapat yang melarang seseorang untuk melakukan ibadah umrah dengan memanfaatkan fasilitas dana talangan maupun mendapat yang memperbolehkannya, sesungguhnya kedua pendapat para ulama di atas sebenarnya sama-sama memiliki alasan yang kuat dengan dukungan dalil-dalil yang rajih. Kedua pendapat itu tidak menutup kemungkinan untuk ditemukan jalan tengahnya, mengingat keduanya memiliki sumber yang sama yaitu Alquran dan Hadis.

Al-Ahkam al-Khamsah (hukum yang lima) merupakan ukuran yang dapat dijadikan patokan atau panduan dalam melakukan suatu amaliyah/ perbuatan mukhallaf. Suatu perbuatan seorang muhkallaf dapat berstatus hukum wajib, sunnahl nadb, mubahljaizlibahah, makruh, dan bahkan dapat pula menjadi haram. Pada umumnya suatu aktifitas mukhallaf dapat berstatus hukum kepada lima hal di atas tergantung keadaannya. Akan tetapi, ada pula perbuatan-perbuatan yang hanya dapat dikategorikan ke dalam satu atau dua jenis status hukum, salah satunya persoalan dana talangan umrah.

Ibadah umrah menjadi sah dan boleh hukumnya sekalipun ia memanfaatkan dana talangan jika memenuhi beberapa persyaratan

${ }^{62}$ Majma Al-Anhar, 4/251; Lihat perinciannya dalam Ilam Al-Muwaqqiien, Ibn Qayyim, 3/137, Kitab Digital Maktabah Syamilah.

${ }^{63}$ Rumah Zakat, "Naik Haji tetapi Berhutang", https:// www.rumahzakat.org/hukum-naik-haji-tetapi-berhutang-3/ diakses pada hari Kamis, 3 Agustus 2017, Pukul 13.06 WIB. 
yaitu: orang yang berhutangkepada pihak ketiga (perseorangan) yang hutangnya tidak ditentukan waktu pembayarannya atau diberikan kelonggaran seluas-luasnya, setidaknya pelunasannya ditangguhkan hingga tiba di Tanah Air. Dana yang dimaksud sudah dapat dipastikan akan digantikan dalam waktu yang dekat. Orang yang berhutang kepada pihak ketiga (perseorangan) kemudian dapat memastikan akan dilunasi oleh anggota keluarganya melalui penjualan aset dalam waktu dekat. Misalnya seseorang yang akan berumrah telah mendapatkan seseorang yang akan membeli aset (semisal tanah, rumah, atau sawah) yang dapat menjamin istitha'ahnya sehingga ia memutuskan untuk meminjam dari seseorang yang lain untuk berangkat umrah. Adapun pembayarannya akan diurus oleh anggota keluarga atau kerabatnya yang ditinggalkan bilamana pembeli menginginkan pelunasan pembayarannya. Mekanisme dhaman bisa dikedepankan dalam hal di atas, di mana keluarga berstatus sebagai dhamin (penjamin) yang akan membayar sejumlah hutang yang ditinggalkan oleh madmun 'anhu dengan menggunakan harta yang sudah jelas dan pasti keberadaannya. ${ }^{64}$ Hukum dhaman untuk hutang dalam kasus di atas adalah sah, sebab jumlah uang yang terhutang dapat dihitung serta berada di dalam perjanjian.Orang yang berhutang memiliki hutang yang dapat diangsur setiap bulan yang alokasi dananya berasal dari sumber pemasukan rutin yang dapat dipertanggung jawabkan, tidak menyulitkan dalam nafkah (jika ia seorang suami), dan tidak memberatkan. Dengan kata lain, ada kemampuan membayar dari seorang yang berhutang tersebut. Contoh untuk persoalan ini ialah Pegawai Negeri Sipil (PNS) yang memang memiliki gaji bulanan yang rutin diperoleh dan dapat diukur. Orang yang berhutang sekalipun bukan Pegawai Negeri Sipil (PNS) dengan catatan ia tetap memiliki sumber pemasukan rutin dari pekerjaan tetapnya. Kondisi ini berlaku bagi karyawan swasta, sekalipun

${ }^{64}$ Dhaman adalah jaminan hutang, atau dalam hal lain menghadirkan seseorang atau barang ke tempat tertentu untuk diminta pertanggungjawabannya, atau sebagai barang jaminan. Tidak sah hukum dhaman untuk hutang yang tidak helas dan tidak berada di dalam perjanjian.Lihat Musthafa Dib alBugha..., h. 281. bukan berstatus sebagai Pegawai Negeri Sipil (PNS), ia tetap dapat dikategorikan memiliki kemampuan melunasi hutangnya. Orangyang berhutang sekalipun ia tidak memiliki uang, tetapi ia memiliki barang berharga semisal emas yang dapat digadaikan di pegadaian syariah atau lembaga penjamin simpanan yang berbasis syariah. Untuk ihktiyati (kehati-hatian) maka jumlah emas yang digadaikan haruslah senilai dengan uang yang dipinjam. Dalam hal jumlah emas yang digadaikan tidak senilai maka dianggap tidak memenuhi kualifikasi istitha'ah kecuali ia memiliki pekerjaan tetap yang menjamin cicilan bulanan. Orang yang mendapatkan arisan yang angsurannya diadakan secara adil antara para anggota dengan akad rela sama rela. Orang tersebut sesungguhnya memperoleh pinjaman secara tidak langsung dari para anggotanya dan memiliki kewajiban membayar cicilan guna memberikan kesempatan anggota yang lain untuk berumrah di masa-masa mendatang.

Sedangkan syarat-syarat yang harus dipenuhi pihak yang memberikan pinjaman meliputi: Pihak memberi pinjaman dana talangan -baik perorangan ataupun lembaga perbankanmengetahui bahwa uang yang ia pinjamkan dipergunakan untuk ibadah umrah, bukan untuk keperluan yang lain. Pihak yang memberi pinjaman dana talangan tidak melarang untuk mempergunakan uangnya untuk ibadah umrah. Pihak yang memberi pinjaman dana talangan tidak menagih uang yang dipinjamkannya selama orang yang peminjam melaksanakan ibadah umrah. Pihak yang memberi pinjaman dana talangan tidak membuat peraturan alakadarnya guna memuluskan proses pinjaman. Harus ada agunan barang senilai dengan nilai pembiayaan yang dikeluarkan. Dalam hal pemberi pinjaman dana talangan adalah lembaga perbankan syariah, ia hanya dapat mengambil keuntungan dari akad di awal, bukan penambahan keuntungan dalam cicilan rutin tiap bulan (sesuai fatwa Majelis Ulama Indonesia).

Pemanfaatan dana talangan pada ibadah umrah menjadi tidak boleh dilakukanapabila mengandung beberapa hal yang tidak me- 
menuhi kriteria istitha'ah yaitu: Jika uang yang dipergunakan untuk berumrah diperoleh melalui jalan haram seperti berasal dari penipuan, kecurangan dalam akad hutang-piutang, dana hasil penggelapan (korupsi), serta modus-modus kejahatan lainnya. ${ }^{65}$ Jika orang yang berhutang sesungguhnya tidak memiliki kemampuan dalam membayar angsuran rutin setiap bulannya. Perbuatan takalluf (asal pinjam) ini dapat terjadi dikarenakan tidak ada sumber penghasilan tetap ataupun tidak memiliki aset yang menjamin kemampuannya dalam melunasi hutang. Jika orang yang berhutang melalui jasa peminjaman lembaga perbankan konvensional yang jelasjelas menggunakan bunga, padahal terdapat pilihan baginya untuk memanfaatkan lembagalembaga perbankan Islam. Selain menyemarakkan syiarribawi, meminjam dari bank konvensional dengan akad bunga juga dapat mengundang kesulitan-kesulitan oleh sebab terputus dari rahmat Allah swt., bahkan mendapatkan ancaman permusuhan dari-Nya. Jika orang yang berhutang melalui jasa bisnis berjenjang/piramida atau money game. Adapun alasan pelarangannya ialah bahwa bisnis piramida ataupun money game mengandung hal-hal yang dilarang oleh syara'seperti riba, gharar, dan lain-lainnya termasuk juga mengambil sesuatu dari orang lain tanpa ganti rugi (QS. An-Nisaal4: 29). Akad dalam arisan berantai, bisnis piramida, dan money game tersebut tidak jelas_ - apakah akad pinjam atau akad hibah, ditambah lagi sifatnya yang spekulatif dan mengandung gharar, sehingga muamalah yang demikian itu adalah dilarang dalam Islam. ${ }^{66}$ Dalil kemaslahatan tidak cukup untuk dikedepankan guna memperbolehkan umrah terhadap keempat alasan larangan penggunaan fasilitas dana talangan. Sebab kemaslahatan yang muncul dalam persoalan kecacatan dalam syarat di atas merupakan maslahatmudharat. Dikatakan maslahatmudharat karena ia bertentangan dengan nash, kondisi yang sama dalam kasus haramnya khamr kendatipun ada beberapa manfaat di samping keharamannya.

${ }^{65}$ Muhammad bin 'Abdurrahman al-Dimasyqi, Fiqih Empat Mazhab, (Bandung: Hasyimi, 2013), h. 162

${ }_{66}$ Abu Yasid (ed)., Fiqh Realitas, (Yogyakarta: Pustaka Pelajar, 2005), h. 155.

\section{Penutup}

Konsep istitha'ah pada ibadah umrah dalam ajaran Islam meliputi kemampuan dalam hal harta benda, makanan, keamanan, dan ketersediaan sarana dan prasarana yang mendukung perjalanan ibadah. Termasuk juga perbekalan bagi keluarga yang ditinggalkan selama perjalanan dan ibadah umrah dilakukan. Tinjauan hukum Islam terhadap ibadah umrah dengan menggunakan dana talangan yaitu bahwa pemanfaatan dana talangan dengan didasari kemampuan melakukan pemenuhan prestasi (pelunasan) adalah dibolehkan sesuai dengan prinsip hukum Islam raf'ul haraj (mengangkat kesulitan) dengan memberikan kemudahankemudahan. Pemanfaatan dana talangan, hukum asalnya ialah mubah, dengan catatan adanya bekal kemampuan bagi penerima manfaat seperti harta tidak bergerak, penghasilan rutin, atau hal lain yang dapat menjamin pelunasan dana talangan yang digunakan. Oleh sebab itu, hendaknya seseorang yang berangkat umrah memperhatikan perbekalan yang ditinggalkan bagi keluarga agar dapat menjamin kelangsungan hidupnya sehingga tidak menimbulkan kemudaratan. Penggunaan dana talangan dapat dilakukan, dengan memperhatikan secara teliti bekal dasar kemampuan harta seseorang, sebagai penjamin pemenuhan prestasi (pembayaran) dana yang digunakan dalam perjalanan dan dalam pelaksanaan ibadah umrah.

\section{Pustaka Acuan}

Ahmadi, Abdul Aziz Mabruk al-, dkk., Fiqh Muyassar: Panduan Praktis Fikih dan Hukum Islam, Jakarta: Darul Haq, tt.

Azzam, Abdul Aziz Muhammad, dan Abdul Wahhab Sayyed Hawas, Fiqh Ibadah: Thaharah, Shalat, Zakat, Puasa, dan Haji, Jakarta: Amzah, 2010.

Azzam, Abdul Aziz Muhammad, Fiqh Muamalat: Sistem Transaksi dalam Figh Islam, Jakarta: Amzah, 2010.

Bugha, Musthafa Dib al-, Fikih Islam Lengkap: Penjelasan Hukum-hukum Islam Madzhab Syafi'i, Solo: Media Zikir, 2009. 
Dimasyqi, Muhammad bin 'Abdurrahman al-, Fiqih Empat Mazhab, Bandung: Hasyimi, 2013.

Faifi, Sulaiman Ahmad Yahya al-, Ringkasan Fikih Sunnah Sayyid Sabiq, Jakarta: Pustaka Al-Kautsar, 2013.

Gayo, M. Iwan, Buku Pintar Haji dan Umrah, Jakarta: Pustaka Warga Negara, 2012.

Jahar, Asep Saepudin, Hukum Keluarga, Pidana \& Bisnis, Jakarta: Kencana Prenadamedia Group, 2013.

Jum'ah,'Ali,Syaikh 'Ali Jum'ah Menjawab 99 Soal Keisalaman, Tangerang: Lentera Hati, 2014.

Jurjawi, Ali Ahmad al-, Indahnya Syariat Islam, Jakarta: Pustaka Al-Kautsar, 2013.

Juzairi, Abdurrahman al-, Fikih Empat Mazhab, Jilid 2, Jakarta: Pustaka Al-Kautsar, 2015.

Kamil, Muhammad Qasim, Halal Haram dalam Islam, Depok: Mutiara Allamah Utama, 2014.

Malibary, Zainuddin 'Abdul 'Aziz al-, Fathul Mu’in, Kudus: Menara Kudus, 1980.

Masjfuk Zuhdi, Masail Fiqhiyah, Jakarta: PT. Toko Gunung Agung, 1997.

Miri, M. Jamaluddin (pent.), Ahkamul Fuqaha: Solusi Problematika Aktual Hukum Islam, Keputusan Muktamar, Munas, dan Konbes Nahdhatul Ulama (1926-2004 M), Jawa Timur: Lajnah Ta'lif Wan Nasyr [LTN], 2007.

Muchtar, Asmaji, Fatwa-fatwa Imam Asy-Syafi' $i$ : Masalah Ibadah, Jakarta: Amzah, 2014.

Muchtar, Asmaji, Dialog Lintas Mazhab: Figh Ibadah dan Muamalah, Jakarta: Amzah, 2015.

Musnad, Muhammad bin 'Abdul 'Aziz al-, Fatwa-fatwa Haji dan Umrah, Jakarta: Pustaka Imam Asy-Syafi'i, 2007.

Shihab, Muhammad Quraish, Haji dan Umrah Bersama M. Quraish Shihab: Uraian Manasik, Hukum, Hikmah, \& Panduan Meraih Haji Mabrur, Tangerang: Lentera Hati, 2012.

Solihin, Ahmad Ifham, Buku Pintar Ekonomi Syariah, Jakarta: PT. Gramedia Pustaka Utama, 2010.
Sya'rawi, Mutawalli, Anta Tas'alu wa al-Islaamu Yujiibu (Anda Bertanya Islam Menjawab), Jakarta: Gema Insani Press, 2007.

Yasid, Abu, (ed).,Fiqh Realitas, Yogyakarta: Pustaka Pelajar,2005.

Zuhaili, Wahbah, al-Figh al-Islam wa Adillatuhu, Damaskus: Daar al-Fikr, 1996.

\section{Internet}

Badri, Muhammad Arifin, "Berhaji dari Talangan Bank", https://almanhaj.or.id/3167-berhajidari-talangan-bank.html, diakses pada hari Kamis, 3 Agustus 20117, Pukul 13.16 WIB.

Hidayat, M. Risyal, TEMPO, "MUI: Boleh Berhaji dengan Uang Pinjaman Bank", https://m. tempo.co/read/news/2012/10/11/136435001/ mui-bolehkan-berhaji-dengan-uang-pinjamanbank, diakses pada hari Kamis, 3 Agustus 2017, Pukul 14.42 WIB.

Kbbi.web.id/umrah (diakses tanggal 2 Desember 2015, Pukul 10.15 WIB)

Rumah Zakat, "Naik Haji tetapi Berhutang”, https://www.rumahzakat.org/hukum-naikhaji-tetapi-berhutang-3/ diakses pada hari Kamis, 3 Agustus 2017, Pukul 13.06 WIB.

Tim Konsultasi Syariah Rumah Zakat, "Hukum Naik Haji tetapi Berhutang", https://www. rumahzakat.org/hukum-naik-haji-tetapiberhutang-3/, diakses pada hari Kamis, 3 Agustus 2017, Pukul 13.06 WIB.

Tim Penulis, "Hukum Berhaji dengan Pinjaman Bank dan Arisan Haji", http://www. jadipintar.com/2013/08/Hukum-BerhajiDengan-Pinjaman-Bank-dan-Arisan-Haji. html, diakses pada hari Kamis, 3 Agustus 2017, Pukul 14.31 WIB.

www.kbbi.web.id/arisan (diakses pada hari Senin, 24 Juli 2017, Pukul 14.54 WIB).

www.kbbi.web.id/dana (diakses tanggal 2 Desember 2015, Pukul 10.17 WIB).

www.mediabpr.com/kamus-binsis-bank/dana_ talangan.aspx (diakses tanggal 2 Desember 2015, Pukul 10.22 WIB). 